\title{
George Eliot,
}

\section{George Henry Lewes i mechanizmy literackiego oddziaływania}

\author{
Marcin Jauksz
}

\section{Zamiast wstępu}

Virginia Woolf w ogłoszonym 20 listopada 1919 roku słynnym eseju o George Eliot napisała nośne i często cytowane zdanie, stwierdzając jakoby Miasteczko Middlemarch, przy wszystkich swych niedoskonałościach, było „jedną z nielicznych angielskich powieści napisanych dla dorosłych"1. W rzadziej cytowanym fragmencie, dotyczącym już wspomnianych niedoskonałości, najważniejsza z brytyjskich pisarek dojrzałego modernizmu pisała tak:

George Eliot słabo panuje nad dialogiem [...], zdaje się ze starczym lękiem cofać przed wysiłkiem emocjonalnego napięcia. Pozwala zbyt wiele mówić swoim bohaterkom. Rzadko trafia się jej szczęśliwy dobór słów. Brak jej tego nieomylnego smaku, który wybiera jedno zdanie i w nim zamyka sens całej sceny. „Z kim pani zatańczy? - spytał pan Knightley na balu u Westonów - Z panem jeśli mnie pan poprosi" - odpowiedziała Emma, i powiedziała dosyć. Pani Casaubon rozprawiałaby przez godzinę, a my zaczęlibyśmy wyglądać przez okno².

Niedoskonałości, które badacze i wielbiciele George Eliot odwołujący się do pochwały Woolf maskują, dla przyszłej autorki Fal mają charakter przepaści, jaka rozwiera się między wrażliwością wiktoriańskiej autorki a zwięzłością, którą ceni Woolf. Fakt, że jako kontrprzykład

\footnotetext{
${ }^{1}$ V. Woolf, George Eliot, [w:] Pochyła wieża. Eseje literackie, wybór i oprac. A. Ambros, Warszawa 1977, s. 188.

2 Tamże, s. 191.
} 
wskazana zostaje Jane Austen, a więc twórczyni z przełomu XVIII i XIX stulecia, wyklucza możliwość, że przyczyną takiego stanu rzeczy był przełom estetyczny zachodzący na fali modernistycznego przewartościowania. Powyższy fragment pokazuje bowiem, że istnieją, zdaniem Woolf, pisarki, które lepiej niż Eliot przetrwały próbę lat. Zdolność do syntezy, zamykania sensów w krótkich, centralnych frazach jest, okazuje się, jak najdalsza od metody literackiego przybliżania rzeczywistości wypracowanej przez Eliot. Nie jest jednak tak, że znużenie, które może stać się udziałem zaczytanego w rozważaniach pani Casaubon odbiorcy, to stan z gruntu niepożądany. Być może Anglia Eliot niewiele ma wspólnego z tą, w której żyła Woolf parędziesiąt lat później, ale anachroniczność nie umniejsza poczucia zadomowienia:

Strumień pamięci i nastroju wlewany przez nią w postacie i sceny jedną po drugiej, dopóki nie ożyje cała dawna sielska Anglia, tak bardzo jest podobny biegowi natury, iż zostawia nas ledwie świadomymi, że można by tu coś skrytykować. Przyjmujemy, czujemy to cudowne ciepło i wyzwolenie ducha, jakie dają nam tylko wielcy twórcy literatury. Kiedy po latach nieobecności wraca się do tych książek, oddychają one, nawet wbrew naszym oczekiwaniom nieuszczuplonym zapasem energii i żaru, że ponad wszystko pragniemy wygrzewać się w ich cieple jak w słońcu odbitym od czerwonego muru otaczającego sad. Takie poddanie się kaprysom farmerów środkowej Anglii i ich żon nie jest pozbawione elementów bezmyślnego przyzwolenia, ale w tych okolicznościach nie ma w tym nic niewłaściwego ${ }^{3}$.

Poczucie zadomowienia w światach przedstawionych proponowanych przez Eliot poświadcza w tym recepcyjnym świadectwie autorki przecież niebezkrytycznej względem techniki pisarskiej Eliot skuteczność stosowanych zabiegów. Woolf potrafiła nazwać ich efekty:

Za to ze swymi szeroko otwartymi ramionami George Eliot zgarnia olbrzymi snop naczelnych cech ludzkiej natury i swobodnie je segreguje z pobłażliwością i pełnym zrozumieniem, które przy ponownym czytaniu nie tylko zapewnia świeżość i swobodę jej postaciom, ale daje im nieoczekiwaną władzę nad naszym śmiechem i łzami

Władza, którą posiadają bohaterowie prozy Eliot, jest zgodna z wolą autorki, której umysł być może, jak stwierdziła Woolf, zbyt wolno pracował, by pozwolić jej tworzyć komedie, ale bez wątpienia miał zdolność oswajania tego, co obce i odległe, a dzięki temu - czynienia tego dla każdego czytelnika bliskim i własnym.

Pytania, które wyrastają ze studium Woolf, dotyczą formuły literackiego angażowania uwagi odbiorcy, które przed rokiem 1919 zdążyły się w znacznej mierze zdezaktualizować jako praktyka twórcza na skutek „postępu intelektu”, by użyć tytułu książki R.W. Mackaya recenzowanej przez Eliot jeszcze w 1851 roku. Niemniej recepcyjne stanowisko autorki zachęca raczej niż odstrasza od poszukiwania związku między modernistycznymi próbami pisarskiej autodefinicji, a przepisami na sukces wypracowanymi przez wiktoriańskich

\footnotetext{
${ }^{3}$ Tamże, s. 187.

${ }_{4}^{4}$ Tamże.
} 
twórców ${ }^{5}$. Zachwyt Woolf, pomimo technicznych mankamentów dostrzeganych choćby w Miasteczku Middlemarch, potwierdza jej skuteczność i pozwala nieco serdeczniej spojrzeć na utopijne niekiedy założenia literackiej komunikacji wypracowanych przez takich twórców, jak Eliot czy George Henry Lewes, niespełniony pisarz i naukowiec zajmujący się biologią i psychologią, a także wieloletni partner Eliot. Jeszcze w połowie XIX stulecia siła oddziaływania narracji o postępie była na tyle silna, że realnymi mogły wydawać się nadzieje, że równoległe do zmian obserwowanych w obrębie nauk społecznych możliwe stanie się wypracowanie skuteczniejszych formuł oddziaływania w literaturze. W przywołanej wyżej recenzji Eliot pisała:

Pan Mackay wierzy, że boskie objawienie nie zawiera się wyłącznie czy przede wszystkim w faktach lub wpływach pojedynczego narodu czy wieku, ale jest współbieżne z historią ludzkiego rozwoju (...). Kluczem do jego objawienia jest rozpoznanie obecności nienaruszalnego prawa obowiązującego tak w świecie materialnym, jak i moralnym - prawa nieodmienności sekwencji, którą uznaje się za podstawę w fizyce, wciąż jednak ignoruje, jeśli chodzi o społeczną organizację, etykę czy naszą religię.

Świat rządzony stabilnymi prawami to mechanizm, którego zasady można i należy, w myśl pozytywistycznego wychowania Eliot, odkrywać. Te dotyczące mechanizmów komunikacji, wpisane w program postępu wiedzy w XIX stuleciu nie są wyjątkiem, a o zależności między wiedzą a spełnieniem $\mathrm{w}$ artystycznej profesji pisał przyjaciel Lewesa i Eliot, jeden z najważniejszych umysłów szkoły pozytywnej w Europie, Herbert Spencer7. Opierając się na jednej z książek Lewesa i fragmentach pisarstwa samej Eliot, chciałbym zwrócić uwagę na doniosłość omawianego tu mitu dla wypracowywania poetyki dziewiętnastowiecznej powieści. I powodów, dla których odejście od niej było wielką koniecznością opisywanej przez Woolf „dorosłej” literatury XX wieku.

\section{Część pierwsza albo „Jak odnieść sukces w literaturze”, poradnik dla średnio-zaawansowanych autorstwa Henry'ego George'a Lewesa}

W swoich dwuczęściowych rozważaniach zatytułowanych The Principles of Success in Literature, opublikowanych po raz pierwszy w „Fortnight Review” w 1865 roku, Lewes formułował pogląd symptomatyczny dla epoki postępu:

\footnotetext{
${ }^{5}$ W ważki sposób komentuje to sama Woolf w szkicu Powieść nowoczesna, pisząc: „Można powiedzieć, że przy swoich prostych narzędziach i prymitywnym surowcu Fielding radził sobie dobrze, a Jane Austen jeszcze lepiej, ale porównajmy ich możliwości z naszymi! Ich arcydzieła brzmią dziwnie prostacko. A jednak analogia między literaturą a, dajmy na to, procesem produkcji samochodów rzadko kiedy wytrzymuje więcej niż pierwszy rzut oka. Wątpliwe, czy w toku stuleci, choć wiele się nauczyliśmy o produkcji maszyn, w dziedzinie tworzenia literatury nauczyliśmy się czegokolwiek. Tu nie osiągnęliśmy postępu. Można tylko powiedzieć, że się posuwamy, raz trochę w jednym kierunku, raz w innym, ale z tendencją do kołowania, gdyby spojrzeć na całą przebytą drogę z wystarczająco wysokiego punktu". Choć nazwisko Eliot tu nie pada, ten fragment napisany w 1919 roku wyjaśnia złożony stosunek Woolf jako czytelniczki do literackiej tradycji, pozwalający jej na otwartość względem alternatywnych formuł obrazowania. Zob.: Pochyła wieża..., s. 285.

${ }^{6}$ G. Eliot, Selected Critical Writings, red. R. Ashton, Oxford 1992, s. 21. Tu i wszędzie dalej, o ile nie podano inaczej, przekład mój - M.J.

${ }^{7}$ Zob. H. Spencer, O wychowaniu umysłowym, moralnym i fizycznym, przeł. M. Siemieradzki, wyd. II, Warszawa 1880 , s. 63 i nast.
} 
Literatura jest jednocześnie przyczyną i efektem społecznego postępu. Pogłębia naszą naturalną wrażliwość i poprzez ćwiczenie umacnia nasze intelektualne zdolności. Jest magazynem zakumulowanego doświadczenia całej rasy, łączy Przeszłość z Teraźniejszością w ciągłą jedność; i tymi zasobami karmi kolejne pokolenia, by być przez nie z kolei nasycaną. A jako że jej ważność wyrasta ku coraz bardziej powszechnemu uznaniu, z konieczności ciągnie ona za sobą coraz liczniejsze grono oddanej służby, napełniając szlachetne umysły szlachetnymi ambicjami ${ }^{8}$.

Uwikłanie literatury w proces cywilizacyjny to diagnoza, która również na ziemiach polskich, dokładnie w tym samym czasie staje się programowym postulatem wschodzącego pokolenia literackiego. Dla Lewesa i większości jego współczesnych ten pogląd ma charakter truizmu; jego waga w obrębie rozważań o mechanizmach literackiego oddziaływania ukazuje pewność mocy sprawczej literatury i - tym samym - autora, który winien być odpowiedzialny, by swoją mocą dysponować w uczciwy sposób. Ogłoszony w „Fortnight Review” esej Lewesa już u schyłku stulecia przedrukowywany był jako akademicki podręcznik, publikacja o charakterze instruktażowym, ale też umoralniającym, czytelny wykład nie tylko zasad reguł kompozycji, ale i analiza mechanizmów osiągania społecznego i rynkowego sukcesu. U podstaw tego pragmatyzmu leżała, co trzeba podkreślić, chęć służenia ideałowi wielkiej sztuki i odróżnienia pisarzy, których uczciwe ambicje zasługiwały na wsparcie, od tych, dla których motorem do działania były jedynie chęć zdobycia poklasku i osiągnięcia konkretnych profitów finansowych. Sukces, o którym instruuje pióro Lewesa, ma wyraziście utylitarny charakter, sam „poradnik” manifestuje zakorzenienie w pozytywistycznym światopoglądzie:

Proponuję, by traktować Zasady osiggania sukcesu w literaturze w przekonaniu, że jeśli jasne rozpoznanie zasad, które leżą u podstaw każdego zwieńczonego sukcesem pisania, może kiedyś zostać osiągnięte, będzie to z nieocenionym pożytkiem dla wielu młodych i przezornych umysłów ${ }^{9}$.

Horyzont właściwego epoce epistemologicznego optymizmu jawi się tu z całą mocą. Jak pisze Lewes, „pomocą jest zrozumienie warunków sukcesu” i łączy się to „z zachętą płynącą z przekonania o ostatecznym zwycięstwie prawdziwych zasad". Entuzjazm ten dziś zbyt łatwo traktować protekcjonalnie i katalogować jako jeden z symptomów pozytywistycznej naiwności, wyraz nadziei, których krach nie był z ówczesnej perspektywy łatwy do przewidzenia. Punkt widzenia Woolf pozwala rozpoznać z kolei, że odejście od retoryki powieści wypracowanej w toku walki o przejrzyste zasady tak pisarstwa, jak i społecznej organizacji nie odbyło się gwałtownie, a charakter towarzyszącej zwrotowi antypozytywistycznemu zmiany w pisarstwie europejskim przełomu stuleci nie był jednorodny. W obrębie wypracowanych i kształtujących również moje myślenie paradygmatów modernizmu choć niewolny od retardacji proces ten postępował jednak w jedynym możliwym kierunku, akcentując względność wszelkich porządków i przekładając skomplikowanie świata na nowe formuły narracyjne. Ale to ta zdezaktualizowana przez doświadczenia pokolenia Woolf opowieść o rozwoju i wielkich nadziejach pozwala pełniej uchwycić logikę artystycznego projektu autorki Middlemarch. Rozwój intelektualny Eliot, jak pisał Jerome Thale, „to typ postępu myśli

${ }^{8}$ G.H. Lewes, The Principles of Success in Literature, red. D. Arms, Berkeley 1901, s. 8.

${ }^{9}$ Tamże, s. 11. 
dziewiętnastowiecznej": od ewangelicznej pobożności, przez utratę wiary, ku próbom ocalenia nadziei w jakikolwiek sensotwórczy porządek w świecie, który pomagać kształtować miały, wbrew wewnętrznemu sceptycyzmowi, jej powieści. „Chciała znaleźć - pisze Thale racjonalną podstawę ludzkiej egzystencji, pozostając sceptyczną względem proponowanych racjonalnych rozwiązań"10.

\section{Część druga (zasadnicza). Śmietanka do herbaty}

Autorka Podróży w świat podkreślała, jak zdumiewać musi fakt zbliżenia się czytelników prozy Eliot do świata prostych farmerów czytelników, których umysłowość jest im obca. Dzieje się tak, że Eliot nie ma w sobie ducha satyry, nie mówi o swoich bohaterach protekcjonalnie, wręcz przeciwnie, „każe nam żyć ich życiem (...) w duchu sympatii”. U podstaw tej zdolności leży jednak biograficzny dramat, los, który zepchnął Eliot na społeczny margines, wymuszając specyficzną perspektywę na świat i ograniczając w pewnym sensie horyzont. W swoim najsłynniejszym eseju o kobiecym pisarstwie Woolf przypominała tę istotną zadrę ograniczenia doświadczenia kobiecego do sfery prywatnej:

Musimy pogodzić się z faktem, iż wszystkie te znakomite powieści - Vilette, Emma, Wichrowe wzgórza, Middlemarch - były pisane przez kobiety, których doświadczenia życiowe nie wykraczały poza zdarzenia dziejące się w czterech ścianach domu zacnego pastora (...). Jednej z nich - George Eliot - po długich udrękach udało się co prawda uciec z zamknięcia, ale tylko po to, by osiąść w odosobnionej willi w St John’s Wood, gdzie żyła w mroku ogólnego potępienia. „Chciałabym, aby wiedziano - pisała - że nigdy nie zaproszę nikogo, kto sam nie wyrazi chęci złożenia mi wizyty”. Żyła bowiem w grzechu z żonatym mężczyzną i jej widok mógłby narazić na szwank cnotę pani Smith. (...) Pomyślałam sobie, że gdyby Tołstojowi przyszło w klasztornym odosobnieniu, żyjąc z zamężną niewiastą, pędzić „poza nawiasem tak zwanego świata” najbardziej nawet umoralniający żywot, to bardzo wątpię, czy napisałby Wojnę i pokój ${ }^{11}$.

Głębia pisarskiego oddechu, o którą na początku XX walczy Woolf, pozwala tu pochylić się nad detalem tekstu z debiutanckich Scen z życia duchownych. Fragment pierwszej zawartej w tym tomie opowieści, Smutnych przygód wielebnego Amosa Bartona, cytuję:

Oboje tedy państwo Hackit z sąsiedniej swej fermy przybyli dziś w godzinę do pani Patten, a także i pani Pilgrim, doktór z pobliskiego miasteczka, który jakkolwiek nieraz arystokratyczne przybierał miny i wydawał późne obiady z zagadkowymi półmiskami i fałszowanym winem, nigdzie przecież doktorskie jego nogi nie spoczywały z taką rozkoszą, jak w tej jednej z ferm wybornych, gdzie myszy były tłuste a gospodyni chorowita.

W tej właśnie chwili opływa on w łakocie jak pączek w maśle. Wesoły ogień płonący na kominku oświetla połyskujący imbryk do herbaty i wyborne domowe grzaneczki; a siostrzenica pani Patten, stara panna lat pięćdziesięciu, która najmniej miłe dla siebie oświadczyny odrzucała, wskutek poświęcenia się dla starej ciotki, ze skromną swobodą wlewa gęstą śmietankę do wonnej jego herbaty.

\footnotetext{
${ }^{10} \mathrm{~J}$. Thale, The Novels of George Eliot, New York 1959, s. 5.

${ }^{11} \mathrm{~V}$. Woolf, Własny pokój, [w:] tejże, Własny pokój - Trzy gwinee, przeł. E. Krasińska, Warszawa 2002, s .90.
} 
Czytelniku! czyś miał kiedy w swych ustach taką herbatę, jaką w tej chwili panna Gibbs podaje doktorowi? Czy znasz tę łagodną i ożywczą słodycz, jakimi napawa podniebienie herbata prawdziwie [w]iejską śmietanką zmieszana? Nie. Boś prawdopodobnie wychowany w mieście i wyobrażasz sobie, że śmietanka jest to płyn rzadki, biały, który w nieskończenie małej ilości za jednego pensa sprzedaje się w rynku, a może też obawa, że płyn ten dla gęstości zaprawiono móżdżkiem cielęcym powstrzymuje cię od używania go i sprawia, że gardło cię szczypie niczym niezaprawiona herbata. Wyobrażasz sobie zapewne, że krowa jest zwierzęciem z gipsu, przyozdabiającym okna mleczarni i wcale nie znasz historii prawdziwej śmietanki, jak napełniała ona dziś jeszcze wymię rosłej i pięknej krowy, z jak rytmicznym dźwiękiem krople jej spadały w donicę Elżbietki, rozkoszną wonią przesycając powietrze, jak następnie przeniesiono ją do mleczarni, tej świątyni czystości i tam pozostawiono w spokoju, ażeby gęsta i żółtawa jej warstwa osiadła na powierzchni mleka, zanim panna Gibbs do dzbaneczka ją zbierze. Jeśli się nie mylę w swych przypuszczeniach, ty czytelniku, wcale nie znasz smaku takiej herbaty, jakiej filiżankę w tej chwili doktor trzyma w swym ręku i sądzę, że w tym względzie posiada on wyższość nad tobą ${ }^{12}$.

Fragment ten, który zasługuje na miano cytatu ryzykownego, gdyż sprawić może, że myśli czytelnika oderwą go od tekstu ku jego kuchni i ukochanym ciepłym napojom, na dobre zaprzepaszczając akt pełnej lektury, jest jednak ważnym dowodem w kwestii tak istotnej dla Woolf. Zaznacza on bowiem status autorytetu, który, mimo skandalu i swego odosobnienia, Evans zdołała sobie wypracować. Gdy Smutne przygody ukazują się anonimowo w Blackwood Magazine, Eliot pozostaje anonimowa, a sukces, który odniesie już wkrótce po publikacji Scen w wydaniu książkowym i - przede wszystkim - Adama Bede, jest jakby niezależny od jej wyborów życiowych i miłosnych. Autorytet Eliot jest zatem autorytetem jej narratorów, których opowieści podbijają ówczesną publiczność literacką.

Już w swym debiutanckim opowiadaniu bowiem i w tym błahym fragmencie powyżej retorycznie zbudowana zostaje przestrzeń, w której Eliot znakomicie odnajdzie się na przestrzeni lat. Potęgi doświadczenia sielankowej prowincji nie da się tu wziąć w karby ironii, dystans budowany między arkadią wiejskiej rutyny a wielkomiejskim zgiełkiem to charakterystyczna dla prozy wiktoriańskiej gotowość podtrzymania romantycznego mitu swojskiej prowincjonalnej przestrzeni stanowiącej ucieczkę przed zagrożeniami wielkiego świata. Gęsta śmietanka jako zagadnienie z zakresu kompozycji powieściowej pozwala zwrócić jednak uwagę na sposób budowania porozumienia między narratorem i czytelnikiem, akcentowania tych elementów świata przedstawionego i (idąc za tytułem całości) scen wokół nich budowanych jako przestrzeni wtajemniczenia, głównych punktów odniesienia.

Przy świadomości, jak ambitny był plan obyczajowej panoramy roztaczającej się z perspektywy probostwa, którą stanowią Sceny z życia duchownych obejmujące historie z fikcyjnego miasteczka na przestrzeni półwiecza, zauważyć należy gotowość skupienia na detalu, która jest nie tylko tym, czym być może chciałaby widzieć je Virginia Woolf - dowodem wyznaczonego kobiecie ograniczonego horyzontu doświadczeń - ale przede wszystkim próbą wskazania w przestrzeni znanej sobie i czytelnikom punktów odniesienia, które ułatwią orientację, porozumienie odnośnie do wspólnych wartości, ale i niemożliwych do wykorzenienia różnic.

${ }^{12} \mathrm{G}$. Eliot, Sceny z życia duchownych, przeł. M. Obrębska, Warszawa 1892, s. 10-11. 
Jak przypomniał Michael York Mason, Eliot w swojej recenzji Wilhelma Riehla Die Bürgerliche /Gesellschaft oraz Land und Leute wskazywała na te z realistycznych formuł, które najlepiej wyjaśniają wybraną przez nią metodę:

Jeśli człowiek o wystarczającym moralnym i intelektualnym zapleczu, którego spostrzeżenia nie byłyby zepsute przez gotowe wnioski lub przez perspektywę profesjonalisty, poświęcił się badaniu historii naturalnej naszych klas społecznych, zwłaszcza drobnych handlarzy, artystów lub chłopstwa - stopnia, w jakim kształtowani są przez lokalne czynniki... i jeśli, po tym wszystkim, dałby nam rezultat swoich obserwacji w książce, bogatej w konkretne fakty, jego praca byłaby cenną pomocą dla społecznego i politycznego reformatora ${ }^{13}$.

Zaangażowanie literatury w praktyczną sferę działań i „upolitycznienie” jej, w pozytywnym dla Eliot znaczeniu, łączy się z chęcią budowania modelu wymiany, w którym to artysta, sprawny obserwator i analityk, syntetyzuje materiał, by ukazać, jak proste prawa zaobserwowane w życiu powodują złożone konsekwencje w społeczeństwie i historii ${ }^{14}$. Wpisana w organicystyczną koncepcję wszelkiej wspólnoty strategia literacka Eliot rozgrywa zagadnienia dziejowych prawideł przez rozpięcie ich w Scenach z życia duchownych między swojską niegdysiejszością a perspektywą współczesnego odbiorcy - dla wzruszeń estetycznych, ale też praktycznego ich wydźwięku. W Smutnych przygodach mowa nie tylko o przyjemnościach towarzyszących piciu herbaty. Mowa też o reformie Kościoła anglikańskiego, wynikających z niej rozłamach w obrębie wspólnoty, mowa o ciężkim losie i niedostatku, jaki wiąże się ze służbą publiczną, mowa o miłości... Wszystkie te wątki da się jednak wyprowadzić z wyraźnego w powyższym fragmencie gestu wykazania „miejskiemu”, obcemu czytelnikowi, jak daleko mu do mitu, który niewątpliwie kultywuje - romantycznego (w jego pojmowaniu) powrotu do źródeł, jaki odprawia się na przykład w magicznym geście nalania śmietanki. Wskazanie dystansu, paradoksalnie, prowadzić ma $\mathrm{w}$ tym przypadku do zbliżenia między nadawczymi instancjami tekstu (czy to autorem pojmowanym na modłę dziewiętnastowieczną, czy też narratorem w ujęciu współczesnego literaturoznawstwa) a odbiorcą. To rozrysowanie pokusy i wpisany w nie uwodzicielski gest, mający przywieść wyobraźnię czytelnika do świata zmysłowego pojednania, stanowią fundament relacji opartej na konkretnych (nawet jeśli wyimaginowanych), swojskich doświadczeniach. Tak uwiedziony czytelnik łatwiej i chętniej wysłucha plotek o wielebnym Bentonie, zadomowiony w Milby chętniej podąży ścieżką smutnych przygód, którą wskaże mu narrator. Działa tu po części, potencjalnie, estetyczna zasada Spencera wyrażona w szkicu Pożytek i piękno, opublikowanym po raz pierwszy w 1852 roku:

Kontrast zachodzący między normami naszego życia i życia przeszłości sprawia, że to ostatnie budzi w nas zajęcie i posiada dla nas charakter romantyczny. Weźmy choćby piknik: jest to chwilowy powrót do pierwotnych zwyczajów; sama ta dziwaczność daje mu charakter poetyczny, którego byśmy w nim nie znaleźli, gdyby należał do naszych zwyczajów; podobnież powab wszelkiej staroświecczyzny leży w tym, że jest ona dla nas nowością ${ }^{15}$.

\footnotetext{
${ }^{13}$ Cyt. za: M.Y. Mason, Middlemarch and Science. Problems of Life and Mind, [w:] George Eliot. Critical Assesments, red. S. Hutchinson, t. III, Critical Essays on Individual Works, Mounfield 1996, s. 353.

${ }^{14}$ Zob. tamże, s. 356.

${ }^{15}$ H. Spencer, Szkice filozoficzne, cz. I, wyd. II, Warszawa 1883, s. 140.
} 
Należy założyć, że taki pogląd na sprawę miał wpływ na debiutanckie opowieści pisarki, jej reformatorskie zapędy wpisane w przygody duchownych, oswojone przez dystans czasu, ukazują, jak zmyślna była próba propagowania postaw, na których Eliot zależało: „tolerancyjnego osądu, litości i współczucia”. Pisała o nich w liście do Wiliama Blackwooda ${ }^{16}$, odmawiając jakichkolwiek zmian w portretach postaci i opisie ich działań, które redaktor pisma sugerował. Ta uczciwość względem własnej fantazji, ubierającej w fabułę niezłomne przekonania wyrosłe na gruncie osobistych doświadczeń łączy się z poglądem na literaturę, który opisywał w swej książce o sukcesie w literaturze Lewes.

Wyobraźnia, szczerość i piękno - te trzy filary wymienia partner Eliot jako kluczowe elementy w swej analizie drogi do sukcesu. Pierwszy z czynników osiągnięcia powodzenia łączy się z przewartościowaniem, do którego dochodzi w XVIII wieku, a co rozważane jest też intensywnie w kolejnym stuleciu, kiedy kwestia produktywnej wyobraźni jako źródła mocy twórczej staje się jednym z centralnych zagadnień dyskusji estetycznych ${ }^{17}$. Niewątpliwie ciekawe jest, że relacje między tymi wartościami estetycznymi układają się w programie Lewesa pod pewnymi względami analogicznie:

Osobiste doświadczenie jest podstawą wszelkiej prawdziwej Literatury. Pisarz musiał przemyśleć kwestie, zobaczyć przedmioty (fizycznie lub mocą wizji), odczuć wcześniej prezentowane teraz uczucia; w przeciwnym wypadku nie będzie miał nad nami władzy (power). Waga nie zależy od unikalności przedmiotu, ale od jego autentyczności ${ }^{18}$.

Szczerość można, obok na przykład historyczności, uznać za jedną z metod kiełznania wyobraźni i takowe kryterium niewątpliwie ułatwia autorowi porozumienie z czytelnikiem - głównie dzięki temu, że panuje między nimi zgoda co do tego, jakiego rodzaju tekst jest nośnikiem przekazywanych prawd.

Siłę wizji, którą zilustrować chciałem przykładem śmietanki, podbudowuje w systemie Lewesa szczerość: „W każdej szczerej mowie - pisze autor Zasad sukcesu w literaturze - jest moc, niekoniecznie wielka moc, ale maksimum tej, na którą mówiący może się zdobyć” ${ }^{19}$. To przekonanie określa ramy, w obrębie których pozostałe dwa czynniki sukcesu mają możliwość udoskonalić siłę przekazu. „Jeśli szczerość nie jest gwarantem mocy, jest na pewno jej warunkiem i żaden prorok ani geniusz nie może bez niej istnieć" ${ }^{20}$.

Wreszcie - zasada piękna, która, jak stwierdził, jest tylko innym imieniem dla stylu. Styl zaś to sztuka, niekomunikowana jak wszystkie inne sztuki, ale podobnie jak one „podporządkowana prawom zbudowanym na podstawie uwarunkowań psychologicznych"21. Ten ważki wątek

\footnotetext{
${ }^{16}$ Cyt. za: D. Lodge, Introduction to Scenes of clerical Life, [w:] George Eliot. Critical Assessments, Mauntfield 1996, s. 23.

${ }^{17}$ Zob. L.C. Lima, The Control of the Imagination and the Novel, [w:] The Novel, vol. 1, History, Geography and Culture, red. F. Moretti, Princeton 2006, s. 44.

${ }^{18}$ G.H. Lewes, The Principles..., s. 35.

${ }^{19}$ Tamże, s. 112.

${ }^{20}$ Tamże, s. 114.

${ }^{21}$ Tamże, s. 138
} 
refleksji Lewesa, podobnie jak jego szczegółowe rozważania o regułach kompozycji i kształtowaniu indywidualnego stylu, znajduje swoje odbicie zarówno w krytycznych, jak i powieściowych dziełach Eliot. Koncentracja autorki na formie, a szczególnie zmiany, jakim w kolejnych utworach podlegała w nich narracja, pozwalają zauważyć, że poszerzanie wiedzy w zakresie tego, co Lewes nazywał psychologicznymi podstawami, przekładało się na próby tworzenia coraz to innych mechanizmów porozumienia między nią a czytelnikami jej dzieł. I prowadzi nas do drugiego fragmentu, który chciałbym przedstawić, wywodzącego się ze wspomnianego przez Woolf Miasteczka Middlemarch. Pochodzi on z początku rozdziału XV, w którym przedstawiony zostaje nowoprzybyły doktor Lydgate:

Wielki historyk - jak sam kazał się nazywać - który miał szczęście umrzeć sto dwadzieścia lat temu i w ten sposób zająć miejsce wśród Kolosów, między których olbrzymimi nogami mrowimy się my żywa małość - otóż ten wielki historyk szczyci się przede wszystkim pomieszczonymi w jego dziele niezliczonymi dygresjami i uwagami, mając je za najoryginalniejsze tego dzieła części, zwłaszcza w początkowych rozdziałach kolejnych ksiąg, kiedy to niejako wystawia fotel na proscenium i z wielką swadą prowadzi z nami rozmowę w pięknej angielszczyźnie. Fielding jednak żył w czasach, kiedy dni były dłuższe (czas bowiem, podobnie jak pieniądze, liczymy według naszych potrzeb), letnie popołudnia - pojemniejsze, a zegar tykał powoli w zimowe wieczory. Nam, późniejszym historykom, nie wolno jednak się ociągać; a gdybyśmy nawet spróbowali, nasza gawęda byłaby śpieszna i bełkotliwa, jakby ktoś gadał, siedząc na składanym stołku w ptaszarni z papugami. Ja w każdym razie mam dostatecznie dużo roboty z rozsupływaniem nici pewnych ludzkich losów i śledzeniem, jak się ze sobą spajają i przeplatają, dlatego też całe światło, jakie mam do dyspozycji, musi być koncentrowane na jednym wątku i nie może się rozpraszać po jakże interesującym terenie wzajemnych odniesień, nazywanym wszechświatem ${ }^{22}$.

Narrator Eliot nie unika konwencji realistycznego pisarstwa, pisząc: „przede wszystkim muszę osobom, które się interesują nowo przybyłym doktorem Lydgate, powiedzieć o nim nieco więcej, niż to wiadome nawet tym mieszkańcom Middlemarch, którzy go najczęściej od przyjazdu widywali". Narrator może powiedzieć więcej, bo więcej wie. To jednak, jak uzasadnia swoje kompetencje, nie mieści się już w ramach standardowych zdolności wiktoriańskiego „opowiadacza”:

Każdy bowiem przyzna, że można kogoś przechwalić i wyidealizować, uczynić godnym zazdrości, wyśmiać, uznać za czyjeś narzędzie, można się w nim zakochać, a przynajmniej wybrać na przyszłego męża - i w gruncie rzeczy nie znać go wcale, chyba że jako zbiór znaków, z których ludzie mogą wyciągać fałszywe wnioski ${ }^{23}$.

To jeden $\mathrm{z}$ tych fragmentów, w którym doświadczanie życia zostaje poniżone względem szans, jakie daje fikcja. Realistyczna poetyka deklaratywnie pozwala tu zobaczyć więcej, ocenić dogłębniej. Człowiek jako poznana w realnym świecie osoba okazuje się tylko „zbiorem znaków"; powieść, która wszak sama jest takim zbiorem, jako przestrzeń świadomie zorganizowana, pozwala lepiej zrozumieć doktora Lydgate, człowieka, którego ambitne plany służby

${ }^{22}$ G. Eliot, Miasteczko Middlemarch, przeł. A. Przedpełska-Trzeciakowska, Warszawa 2005, t. I, s. 170-171.

${ }^{23}$ Tamże, s. 171. 
społecznej mają, niby meduza (wykorzystuję tu porównanie Eliot), rozmyć się z czasem, podporządkowane determinacji i planom Rozamundy Vincy, jego przyszłej żony.

Kompetencje, którymi wykazuje się w dwóch powyższych fragmentach narrator Eliot, ukazują chęć budowania wspólnoty komunikacyjnej na podstawie łatwiejszych do wychwycenia, bo literackich rejonów doświadczenia - taką funkcję pełni przywołany wcześniej Fielding. Analityczne kompetencje pisarki wyraźnie pokazują też jej naukowe obycie i psychologiczną przenikliwość. Eliot nie zrywa jednak z tak przydatnym kryterium zdrowego rozsądku, a potoczne doświadczenie („każdy bowiem przyzna...”) jest ostatecznym probierzem głoszonych ex cathedra prawideł. To jeden z tych fragmentów, które można by wybrać jako przykład płynnego przejścia między tym, jak Evans przedstawiała (a być może także postrzegała) samą siebie a kompetencjami jej narratorów. Jednocześnie to właśnie fragmenty takie jak ten pozwoliły narysować granicę, która ostatecznie poprowadzi krytykę literacką i profesjonalne studia nad literaturą ku wypracowaniu dwudziestowiecznych kategorii opisu instancji twórczych.

W przypominanym przez najważniejszych anglosaskich badaczy w dziewiętnastowiecznej fikcji retorycznych strategii (od Kathleen Tillotson, przez Wayna C. Bootha aż po Wolfganga Isera) eseju Edwarda Dowdena, opublikowanym w 1877 roku, pojawia się znacząca, bo niezwykle wcześnie użyta kategoria „autora implikowanego”; dla mnie jednak bardziej interesujące od najczęściej cytowanego fragmentu tej pracy jest podejście krytyka do efektu, jaki „drugie ja” Eliot wywiera.

Stoi ono w pewnej odległości od tego pierwszego ja i różni się też odeń znacząco. Ukazuje nam osobę z mniejszą rezerwą, wolną od lokalnych, czasowych ograniczeń mowy a także milczenia; nie rozstrzyga o ludziach po ich ciele, jest czymś więcej niż zwyczajna jednostka; wypowiada sekrety, ale takie, które ludzie wszystkich wieków są w stanie wychwycić, podczas gdy ubezpiecza ją od tyłu wiarygodna historyczna pewność siebie wynikająca z impertynenckiej zdolności obserwacji i krytyki. To z tym drugim ja George Eliot, nie zaś z realną historyczną osobą mamy do czynienia. A gdy po zamknięciu jej książek patrzymy przed siebie oczami umysłu, oglądany przez nas spektakl ukazuje wielką naturę, która cierpiała, ale teraz już dotarła do celu, która była zdumiona, ale teraz odnalazła wskazówkę sobie potrzebną, stojącą przed nami nie bez widocznych na twarzy oznak walki i cierpienia ale jednocześnie stanowczą i tym samym w posiadaniu siły, która czyni mistrzostwo w kierowaniu swymi czynami możliwym. Walka jeszcze się nie skończyła, ból może powrócić, ale wiemy już, po której stronie leżeć będzie zwycięstwo.

Osobisty akcent w pisarstwie George Eliot nie koliduje z ich dramatyczną prawdziwością, wzmacnia tylko siłę z którą chwytają one za serce i zdobywają umysł czytelnika ${ }^{24}$.

Poczucie władzy, jakie ma pisarz, jest w przestrzeni aksjologii wyznawanej przez Eliot i Lewesa w zasadniczy sposób ograniczone. Nie chodzi, jak pokazuje partner Evans w swej książce o sukcesie w literaturze, o to, by przeliczać wartość dzieła na ilość sprzedanych egzemplarzy, ale o to, by zdobywać uznanie umysłów wybitnych, współodczuwających z pisarzem.

${ }^{24}$ E. Dowden, Studies in Literature, London 2013, s. 240-241. Podkreślenie w przekładzie moje - M.J. 
To powaga uznania, jak pisze Lewes, jest prawdziwą nagrodą Literatury, miarą mocy, jaką dysponuje autor. Używane przez filozofa angielskie słowo power może być tłumaczone jako moc albo jako władza; w zależności od kontekstu wyraża ono potencjał pisarstwa, które, oparte na konkretnym systemie wartości, prowadzi do przemiany tych wybranych, którzy faktycznie poczuli zapach śmietanki unoszący się nad filiżanką doktora z Milby.

\section{Zakończenie}

Pierwszego stycznia 1873 roku, informując w swoim dzienniku o tym, że ósmy i ostatni tom Middlemarch ukazał się w grudniu dopiero co zakończonego roku, Eliot zaznaczała, że żadna z jej wcześniejszych książek nie była przyjęta z większym entuzjazmem. „Otrzymałam wiele ciepłych zapewnień o jej pozytywnym wpływie na poszczególne umysły [individual minds]"25. Ten wpływ i radość płynąca $z$ faktu jego poświadczenia to i dla Eliot, i - jak sama stwierdziła - również dla Lewesa, wybierającego, dodajmy, dla partnerki do czytania tylko przychylne recenzje, największa satysfakcja. Sama pisarka mówi o mile połechtanej miłości własnej, ale też o znaczeniu, jakie ten rozwój jej duchowej egzystencji ma w walce z doganiającymi ją oznakami starości ${ }^{26}$.

Michael Davies, komentujący w zakończeniu swej pionierskiej pracy George Eliot and the Nineteenth-century Psychology, wskazywał na jej wysoką świadomość sprawczej roli literatury i jednocześnie jej zdolności do tworzenia świata poza przestrzenią naukowych diagnoz. Robił to w kontekście rozważań Eliot nad formą w sztuce, które odnalezione wśród zapisków prywatnych mają dla badaczy twórczości pisarki status osobnego, niezwykle ważnego szkicu. Pisze Davies:

Słowa Eliot są ciekawe jako medytacja o mocy umysłu, mocy, która może być przywołana i wykorzystana dzięki celowemu podstępowi w ramach tworzenia literatury. Jak zwykle jest tu świadoma ciągłego procesu „grupowania i asocjacji”, które konstytuują umysł, wybór frazy zaś wskazuje na wpływ tradycji asocjacjonistycznej w psychologii na jej reprezentacje życia umysłowego i wiele modeli umysłu, które wykorzystywała ${ }^{27}$.

Zależność dobieranych form od analiz psychologicznych Lewesa wymyka się w tym miejscu poza obręb prywatnej relacji, ukazując zasadę, która rządzi kształtowaniem się fundamentalnego dla powieści realistycznej konsensusu, o którym pisała Elisabeth Deeds Ermarth, wypracowania strategii obrazowania, która zdradzałaby mechanizmy uprawomocnienia takiego a nie innego sposobu reprezentacji ${ }^{28}$. W tym kontekście wyraźny głos narratora w obu prezentowanych fragmentach prozy Eliot ma jako metakomentarz status głosu legislatora, który określa doraźne mechanizmy porozumienia adekwatne do prezentowanych aspektów rzeczywistości. Doświadczenie, które rządzi pierwszym tu przywoływanym fragmentem prozy Eliot i doświadczenie literackie zawarte we fragmencie drugim - oba ukazują istotność wspólnej, autorskiej i czytelniczej relacji względem historii prywatnej i tradycji sensu largo

\footnotetext{
${ }^{25} \mathrm{G}$. Eliot, The Journals of George Eliot, red. M. Harris, J. Johnson, Cambridge 1998, s. 142-143.

${ }^{26}$ Tamże, s. 143.

${ }^{27}$ M. Davies, George Eliot and the Nineteenth-century Psychology: Exploring the Unmapped Country, Aldershot 2006.

${ }^{28}$ Zob. E.D. Ermarth, Realism and Consensus in the English Novel. Time, Space, Narrative, wyd. II, Edinburgh 1998,

s. XIX i nast.
} 
w imię możliwości komunikacji i wywierania wpływu (lub pobierania lekcji - w zależności od perspektywy). Chociaż zatem Woolf w swoim eseju poświęconym Eliot pisze o tym samym rozchwianiu postawy twórczej, którą dostrzegał cytowany wcześniej Dowden, postawy, która sprawia, że „już nawet w jej wczesnych książkach spotykamy ślady owego udręczonego ducha, tej istoty wymagającej, wątpiącej i zawiedzionej, jaką była sama"29 ${ }^{2}$ niemniej siła całego dzieła pisarki sprowadza czytelnika (z każdego stulecia) niezmiennie do roli ucznia rozpoznającego ukryte mechanizmy budowania się światopoglądu. Bo wszak, jak pokazywała Woolf, nie o nostalgiczne wskrzeszanie świata, który przeminął lub właśnie przemija w tych powieściach chodziło i chodzi:

Ale spróbujmy bez litości odprawić jej bohaterki i samą George Eliot zamknąć w granicach bukolicznego świata jej „najdalszej przeszłości”, a nie tylko umniejszymy jej wielkość, ale także pozbawimy ją właściwego smaku. O istnieniu tej wielkości nie wątpimy ani przez chwilę. Szerokość spojrzenia, wyraźne, z rozmachem rzucone główne kontury szkicu, czerstwość bijąca od jej wczesnych książek, dociekliwość i bogactwo refleksji w książkach późniejszych kuszą nas do tego, aby poświęcić im więcej czasu i rozwieść się aż poza zakreślone nam granice ${ }^{30}$.

Quid erat demonstrandum, chciałbym mieć nadzieję.

${ }^{29}$ V. Woolf, George Eliot, s. 188.

${ }^{30}$ Tamże, s. 191. 


\title{
SEOWA KLUCZOWE:
}

\author{
poetyka powieści
}

\section{AbSTRAKT:}

Celem artykułu jest analiza wybranych wątków przemian w obrębie poetyki dziewiętnastowiecznej powieści, do których dochodzi pod wpływem rozwoju psychologii i innych nauk społecznych. Przypadek intelektualnej interakcji między George Eliot a Georgem Henrym Lewesem, partnerów tak w życiu, jak i w zainteresowaniach literackich, pozwala zaobserwować jak bliskie były ambicje realistycznych pisarzy oraz badaczy życia społecznego w zakresie odkrywania mechanizmów ludzkiej psychiki. Sceny z życia duchownych oraz Miasteczko Middlemarch, czytane z perspektywy Virginii Woolf, pełne sa przykładów na to, w jaki sposób studia Lewesa wpłynęły na literackie projekty Eliot. 


\section{doświadczenie}

\section{modernizm}

\section{NOtA O AUTORzE:}

Marcin Jauksz - doktor, literaturoznawca i filmoznawca, adiunkt Zakładu Literatury Pozytywizmu i Młodej Polski w Instytucie Filologii Polskiej UAM; w 2010 roku obronił rozprawę doktorską Krytyka dziewiętnastowiecznego rozumu. Źródła i konteksty „Pałuby” Karola Irzykowskiego nagrodzoną w Konkursie im. Konrada i Marty Górskich w 2011 roku; interesuje się psychologizmem w prozie późnego wieku XIX i kształtującymi się wówczas zasadami kompozycji dzieła literackiego, ostatnio tropi też poetów zagubionych na "marginesach cywilizacji”. Stypendysta rządu francuskiego w latach 2008 - 2009; publikował m.in. w „Wieku XIX”, „Porównaniach”, „Lampie” i „Polonistyce”. 